\title{
PENGARUH JIGSAW DAN MOTIVASI BELAJAR PADA MAPEL BAHASA INGGRIS “REPORTED SPEECH” TERHADAP HASIL BELAJAR SISWA KELAS X SMA TAMAN MADYA KOTA PROBOLINGGO
}

\author{
Niken Sholi Indrianie \\ SMA Negeri 1 Probolinggo \\ Email: nikensholi@gmail.com
}

\begin{abstract}
ABSTRAK
Penelitian ini bertujuan untuk mengetahui hasil belajar siswa pada mata pelajaran bahasa Inggris "Reported Speech" dengan menggunakan pembelajaran cooperative learning model Jigsaw yang dikaitkan dengan motivasi belajar siswa. Penelitian ini dilaksanakan di SMA Taman Madya Kota Probolinggo dengan menggunakan pendekatan kuantitatif. Data penelitian berupa observasi aktivitas guru, aktivitas siswa dan kemampuan mengerjakan soal dalam bahasa Inggris "Reported Speech". Data Penelitian bersumber pada peserta didik kelas X dan observer yang melaksanakan penelitian di sekolah tersebut. Hasil penelitian menunjukkan bahwa pembelajaran cooperative learning model Jigsaw terlaksana dengan baik sesuai dengan sintak pembelajaran yang direncanakan. Aktivitas setiap siswa yang belajar secara berkelompok dapat berperan dan dapat melaksanakan fungsinya dengan baik. Kemampuan setiap siswa dalam belajar dan mengajarkan materi/pokok bahasan kepada temannya yang lain dalam kelompok dapat berlangsung dengan baik sehingga temannya mampu untuk memahami dan memecahkan masalah bahasa Inggris "Reported Speech" dengan baik, dan pada langkah penyelesaian serta langkah mengerjakan soal evaluasi (tes) dapat terlaksana dengan baik serta menunjukkan hasil belajar yang cukup meningkat.
\end{abstract}

Kata kunci: cooperative learning, jigsaw, motivasi belajar, hasil belajar

\begin{abstract}
This research is aimed to know the result of the study of the students on the English subject "Reported Speech" by using cooperative learning strategies model jigsaw in relation to the students' motivation. This research is conducted on SMA Taman Madya, Probolinggo city by using quantitative approach. The data of the research is collected from the observation to the teacher, students' activity, and the ability on English test "Reported Speech". The source of the data are the students of tenth grade and observation on the school's activity. The result of this study shows that the cooperative learning model jigsaw is well-applied in parallel to the lesson plan. The students' activity in a group is wellconducted ad able to follow its function. The skill of the students in the learning and teaching of material and topics to the group is well-conducted and resulted in clear understanding and ability to solve the problem of English "Reported Speech" by the other students, as well as a well-conducted finishing steps and a well-established steps on doing the evaluation to show an enhanced result of study.
\end{abstract}

Keywords: cooperative learning, jigsaw, learning motivation, result of study

\section{PENDAHULUAN}

Hakikat belajar adalah proses interaksi terhadap semua situasi atau kondisi yang ada di sekitar individu.
Belajar dapat dipandang sebagai proses yang diarahkan kepada tujuan dan proses berbuat melalui berbagai pengalaman. Belajar tidak dapat dipisahkan dari 
kehidupan manusia dan kegiatan tersebut bisa terjadi dimana saja, baik dalam lingkup keluarga, sekolah maupun masyarakat, secara sengaja maupun tidak disengaja. Belajar merupakan proses melihat, mengamati, dan memahami sesuatu dan dari kegiatan tersebut akan membuat suatu perubahan. Seseorang dianggap telah belajar bila ia mampu menunjukkan perubahan sebagaimana yang disampaikan oleh Uno, et all (2008) menyatakan bahwa belajar adalah perubahan persepsi dan pemahaman.

Membahas tentang makna belajar, maka Wahidmurni, et all (2010) menjelaskan bahwa sesorang dapat dikatakan belajar apabila dia juga telah berhasil dalam belajar sehingga dia mampu menunjukkan adanya perubahan dalam dirinya. Perubahan-perubahan tersebut bisa dari segi kemampuan berpikir, ketrampilan atau sikap terhadap sesuatu objek. Pada dasarnya belajar merupakan proses perubahan yang berlangsung dalam jangka waktu tertentu melalui pemberian pengetahuan, latihan atau ketrampilan maupun pengalaman.

Belajar merupakan suatu proses kegiatan pembelajaran yang melibatkan banyak komponen, antara lain guru, siswa, bahan ajar, media serta model pembelajaran. Agar tercipta proses pembelajar yang maksimal dibutuhkan kondisi yang mendukung, dan salah satu kondisi yang dapat mendukung adalah kecermatan guru dalam memilih model dalam pembelajaran secara tepat. Rusman (2011) menyatakan bahwa pembelajaran merupakan suatu sistem yang terdiri dari komponen yang saling berhubungan. Komponen-komponen tersebut adalah tujuan, materi, metode atau model, dan evaluasi. Komponenkomponen tersebut harus menjadi pertimbangan guru dalam memilih dan menentukan model-model pembelajaran yang digunakan, karena Sanjaya. W (2008) mengungkapkan bahwa suatu strategi pembelajaran yang tepat sangat dibutuhkan supaya proses belajar dapat berhasil dengan baik.

Pelaksanaan pembelajaran bahasa Inggris, khususnya pada materi "reported speech" siswa dalam praktiknya seringkali mengalami kesulitan, salah satu penyebabnya adalah lemahnya ketrampilan siswa dalam memahami struktur kalimat atau grammar.

Guru sebagai tenaga pendidik harus senantiasa melakukan upaya-upaya dan inovasi dalam pembelajaran bahasa Inggris sehingga tujuan pembelajaran dapat terealisasi secara maksimal. Upaya yang dapat dilakukan adalah menggunakan model pembelajaran yang dapat meningkatkan keterampilan siswa dalam bahasa Inggris khususnya untuk memecahakan masalah kelemahan siswa yang berkaitan dengan grammar reported speech. Salah satu model pembelajaran yang dapat digunakan untuk meningkatkan keterampilan siswa dalam bahasa Inggris pada pokok bahasan reported speech adalah dengan menggunakan pembelajaran kooperatif model jigsaw.

Cooperative Learning merupakan salah satu model pembelajaran yang dapat didefinisikan sebagai sistem kerja/belajar kelompok yang tersetruktur. Falsafah yang mendasari pembelajaran Cooperative Learning (pembelajaran gotong royong) dalam pendidikan adalah pembelajaran yang menekankan bahwa manusia adalah makhluk sosial. Cooperative Learning adalah suatu strategi belajar mengajar yang menekankan pada sikap atau perilaku bersama dalam bekerja atau membantu di antara sesama dalam struktur kerjasama yang teratur dalam kelompok, yang terdiri 
dari dua orang atau lebih dengan suasana kondusif agar siswa dapat mengembangkan pengetahuan, sikap, nilai serta keterampilan sosial yang bermanfaat bagi kehidupannya di masyarakat.

Suyitno ( 2011), menjelaskan bahwa ada lima unsur yang harus diterapkan untuk bisa dikatakan Cooperative Learning. Kelima unsur tersebut adalah: (1) Saling ketergantungan positif, semua anggota kelompok bekerja secara sinergis dalam mengembangkan kelompoknya, sehingga setiap anggota kelompok bergantung dan bertanggung jawab terhadap anggota yang lainnya, dalam kelompok itu. (2) Tanggung jawab perseorangan, dengan tugas yang berbeda-beda, setiap anggota kelompok bertanggung jawab menyelesaikan tugasnya dengan sebaik-baiknya untuk dilaporkan kepada teman-teman sekelompoknya. (3) Tatap muka, dalam pembelajaran Cooperative Learning setiap kelompok harus diberikan kesempatan untuk bertatap muka dan berdiskusi. Kegiatan interaksi ini akan memberikan para pembelajar membentuk sinergi yang menguntungkan semua anggota dan inti dari sinergi ini adalah menghargai perbedaan, memanfaatkan kelebihan, dan mengisi kekurangan. (4) Komunikasi antar anggota, komunikasi dalam kelompok harus merata pada setiap individu anggota kelompok. Unsur ini menghendaki agar para pembelajar dibekali dengan bebagai ketrampilan berkomunikasi, karena keberhasilan suatu kelompok juga bergantung pada kesediaan para anggotanya untuk saling mendengarkan dan mengutarakan pendapat mereka. Ketrampilan berkomunikasi dalam kelompok juga merupakan proses panjang yang sangat bermanfaat dan perlu dialami untuk memperkaya pengalaman belajar dan pembinaan perkembangan mental dan emosional para siswa.(5) Evaluasi proses kelompok, untuk melakukan refleksi apakah kerja kelompoknya sudah baik atau perlu ada perbaikan. Dalam hal ini perlu waktu khusus bagi kelompok untuk mengevaluasi proses kerja kelompok dan hasil kerja sama mereka agar selanjutnya bisa bekerja sama dengan lebih efektif.

Mengduo dan Xiaoling (2010) menyampaikan bahw banyak alternatif model pembelajaran yang dapat diterapkan di kelas untuk pembelajaran bahasa Inggris, salah satunya adalah model jigsaw yang dikembangkan oleh Elliot Aronson dimana model ini memberikan kesempatan kepada siswa untuk saling bekerjasama sehinggqa siswa dapat belajar lebih luas dalam suasana yang kondusif yang memungkinkan siswa memperoleh dan mengembangkan pengetahuan, sikap, nilai serta keterampilan sosial yang bermanfaat bagi kehidupannya di masyarakat. Hal ini yang mebuat Jigsaw menjadi sangat efektif. Seperti yang diungkapkan Lie (2007), bahwa pembelajaran kooperatif model jigsaw adalah sebuah model pembelajaran kooperatif yang menitik beratkan kepada kerja kelompok siswa dalam bentuk kelompok kecil, dengan cara siswa belajar dalam kelompok kecil yang terdiri atas empat sampai dengan enam orang secara heterogen maka siswa dapat bekerja sama untuk saling ketergantungan positif dan bertanggung jawab secara mandiri. Haryanto (2012) juga menambahakan bahwa dalam model jigsaw ini siswa memiliki banyak kesempatan untuk mengemukanakan pendapat, dan mengelolah imformasi yang didapat sehingga dapat meningkatkan keterampilan berkomunikasi, anggota kelompok bertanggung jawab atas keberhasilan kelompoknya dan ketuntasan bagian materi yang dipelajari, dan dapat menyampaikan 
kepada kelompoknya, dengan demikian penerapan model pembelajaran ini akan memungkinkan siswa menjadi aktif serta mendorong motivasi siswa yang pada akhirnya diharapkan dapat meningkatkan hasil belajar siswa, selain itu penggunaan model ini dapat membantu guru secara efektif dan efisien dalam proses pembelajaran di kelas sehingga kegiatan pembelajaran tidak di dominasi oleh guru serta siswa tidak akan merasa bosan dalam mengikuti atau menerima pelajaran (Lie A. 2007).

Penggerak utama dari kegiatan pembelajaran di kelas adalah guru, karena guru memiliki tanggung jawab langsung sebaga penterjemah kurikulum ke dalam kegiatan pembelajaran dan bukan satusatunya sebagai sumber utama pengetahuan. Hal itu dapat dilihat dari tugas dan peran guru sebagai tenaga pengajar antara lain yaitu sebagai komunikator, fasilitator, model, evaluator, sumber belajar, administrator dan motivator. Berkaitan dengan tugas tersebut maka guru harus memiliki keterampilan dalam melaksanakan pembelajaran di kelas dengan sebaik-baiknya, dan supaya siswa dapat mencapai hasil belajar yang optimal maka guru harus bisa menjalankan tugasnya sebagai seorang motivator yang baik sehingga dapat merangsang dan menumbuhkan motivasi siswa secara maksimal.

Motivasi adalah keadaan dalam pribadi seseorang yang mendorong keinginan individu untuk melakukan kegiatan-kegiatan tertentu guna mencapai suatu tujuan. Motivasi yang ada pada seseorang akan mewujudkan suatu perilaku yang diarahkan pada tujuan mencapai sasaran kepuasan.

Motivasi merupakan faktor yang sangat penting dalam belajar, karena motivasi dapat memberi semangat kepada siswa dalam kegiatan belajarnya sehingga cenderung mendorong siswa untuk menemukan kegiatan akademik yang berarti dan bermanfaat. Pada saat siswa menerima aktivitas pelajaran di situlah motivasi untuk belajar muncul yang dapat menimbulkan dorongan-dorongan atau perhatian yang diinginkan, seperti yang disampaikan oleh Dimyati dan Mujiono (2009) bahwa motivasi belajar merupakan segi kejiwaan yang mengalami perkembangan, hal tersebut senada dengan pendapat Hamalik (2008) mengatakan bahwa motivasi adalah perubahan energi dalam diri (pribadi) seseorang yang ditandai timbulnya perasaan dan reaksi untuk mencapai tujuan.

Motivasi belajar merupakan daya penggerak psikis dari dalam diri seseorang agar dapat melakukan kegiatan belajar dan menambah pengalaman maupun keterampilan, sesuai dengan penjelasan Aritonang. K T (2008) dan Sriyanti (2009) bahwa motivasi adalah sebagai daya penggerak siswa dalam aktivitas belajarnya.

Tsay. M, and Brady. M, (2010) melaporkan bahwa beberapa penelitian bidang pendidikan yang menerapkan strategi pembelajaran kooperatif, ternyata pengaruhnya dapat memotivasi dan melibatkan siswa dalam proses belajar mengajar yang hasil pembelajarannya dapat meningkat. Hal ini seiring dengan fungsi motivasi Hamalik (2008) yaitu; (1) motivasi mendorong timbulnya tingkah laku atau perbuatan, tanpa motivasi tidak akan timbul suatu perbuatan misalnya keinginan untuk belajar; (2) motivasi berfungsi sebagai pengarah yang artinya mengarahkan perbuatan untuk mencapai tujuan yang diinginkan; (3) motivasi sebagai penggerak yang artinya menggerakkan tingkah laku seseorang untuk berbuat atau bertindak.

Berdasarkan beberapa penjelasan diatas tentang motivasi maka dapat disimpulkan bahwa motivasi belajar adalah suatu dorongan dari dalam diri yang 
membuat seseorang sadar untuk melakukan aktivitas belajar guna mencapai tujuan tertentu yang mengakibatakan perubahan terhadap hasil belajar. Motivasi bukan hanya sebagai penentu terjadinya suatu perbuatan, tetapi juga menentukan hasil perbuatan. Motivasi akan mendorong seseorang ingin belajar atau melakukan sesuatu perbuatan dengan sungguh-sungguh yang selanjutnya akan memberikan pengaruh terhadap hasil pekerjaan atau menentukan hasilnya.

Tercapai tidaknya tujuan pembelajaran salah satunya adalah dari hasil belajar yang diraih siswa, dan guru dianggap sebagai orang yang paling bertanggungjawab terhadap hasil belajar. Anggapan seperti itu tidak sepenuhnya benar, mengingat masih banyak sekali komponen pendidikan yang berpengaruh terhadap hasil belajar. Namun demikian, guru merupakan komponen yang paling strategis dalam proses pembelajaran. Oleh karena itu, sangatlah penting bagi guru untuk selalu mengupayakan hal-hal yang dapat meningkatkan hasil belajar secara maksimal dan efektif mengingat hasil belajar merupakan tujuan akhir dilaksanakannya kegiatan pembelajaran. Hasil belajar dapat ditingkatkan melalui usaha sadar yang dilakukan secara sistematis mengarah kepada perubahan yang positif yang kemudian disebut dengan proses belajar. Akhir dari proses belajar adalah perolehan suatu hasil belajar siswa. Semua hasil belajar tersebut merupakan hasil dari suatu interaksi tindak belajar dan tindak mengajar. Bagi guru, tindak mengajar di akhiri dengan proses evaluasi hasil belajar, sedangkan bagi siswa, hasil belajar merupakan berakhirnya penggal dan puncak proses belajar (Dimyati dan Mudjiono, 2009).

Menurut Sudjana (2010), hasil belajar adalah suatu kemampuan yang harus dimiliki siswa setelah menerima pengalaman belajar. Selanjutnya Depdiknas (2006) mengemukakan bahwa hasil dari kegiatan belajar ditandai dengan adanya perubahan perilaku ke arah positif yang relatif permanen pada diri orang yang belajar. Hamalik (2006), menambahkan bahwa hasil belajar yang diperoleh dapat diukur melalui kemajuan yang dicapai siswa setelah belajar dengan sungguh-sungguh. Hasil belajar akan menunjukkan terjadinya perubahan tingkah laku pada diri siswa yang dapat diamati dan diukur melalui perubahan sikap dan keterampilan, dan perubahan tersebut dapat diartikan terjadinya peningkatan dan pengembangan yang lebih baik dibandingkan dengan kondisi sebelumnya.

Antara hasil belajar dan motivasi memiliki keterkaitan dan pengaruh yang sangat kuat karena salah satu faktor yang mempengaruhi hasil belajar adalah motivasi. Siswa yang memiliki motivasi yang tinggi dalam belajar akan memiliki dorongan dan kesadaran yang kuat dalam usaha maupun upaya dalam belajar yang memungkinkan akan memperoleh hasil belajar yang tinggi pula. Agar siswa dapat memiliki motivasi belajar yang kuat maka perlu dilakukan upaya-upaya yang dapat membangkitkan motivasi dalam pembelajaran di sekolah, antara lain dengan menerapkan modelmodel pembelajaran yang menarik dan inovatif.

Menyadari pentinganya inovasi modelmodel pembelajaran yang dapat membangkitkan motivasi siswa supaya mencapai hasil belajar yang maksimal, maka penulis ingin melakukan penelitian tentang pengaruh pembelajaran kooperatif model jigsaw dan motivasi belajar terhadap hasil belajar bahasa Inggris "reported speech"siswa kelas X SMA Taman Madya Kota Probolinggo. 


\section{METODE}

Penelitian ini merupakan penelitian eksperimen yaitu melakukan kegiatan yang direncanakan dan dilaksanakan oleh peneliti untuk mengumpulkan bukti- bukti yang ada, sedangkan pendekatan yang digunakan adalah pendekatan kuantitatif yang bersifat eksperimen dan menggunakan analisis statistik SPSS Ver. 18.00.

Jenis data dalam penelitian ini adalah data primer yaitu data yang diambil oleh peneliti sendiri, dan data sekunder adalah data yang diperoleh bukan dari peneliti, misal laporan nilai raport, atau nilai ulangan harian. Sumber data adalah data diperoleh melalui observasi partisipan dan non partisispan (data diperoleh dari pihak lain misal, lembaga).

Penelitian ini dilaksanakan pada kelas X di sekolah SMA Taman Madya Kota Probolinggo, yang mana pada masingmasing kelompok menggunakan Cooperative Learning model Jigsaw dan mengisi angket motivasi..

Data yang dikumpulkan peneliti dalam penelitian ini yaitu berupa data hasil belajar bahasa Inggris peserta didik yang diperoleh dengan menggunakan instrumen test hasil belajar yang diberikan sebagai tes kemampuan peserta didik.
Pengumpulan data dengan metode tes digunakan untuk mendapatkan informasi tentang kemampuan peserta didik setelah mengikuti pembelajaran. Pada penelitian ini menggunakan soalsoal pilihan ganda, sedangkan angket motivasi berupa angket tertutup yang tujuannya untuk mengetahui motivasi siswa terhadap pembelajaran bahasa Inggris dengan menggunakan model jigsaw.

\section{HASIL DAN PEMBAHASAN}

Model pembelajarn kooperatif jigsaw terdapat kelompok asal dan kelompok ahli, kelompok asal yaitu kelompok induk siswa yang beranggotakan siswa dengan kemampuan, asal, dan latar belakang keluarga yang beragam. Kelompok asal merupakan gabungan dari beberapa ahli. Kelompok ahli yaitu kelompok siswa yang terdiri dari anggota kelompok asal yang berbeda yang ditugaskan untuk mempelajari dan mendalami topik tertentu serta menyelesaikan tugas-tugas yang berhubungan dengan topiknya untuk kemudian dijelaskan kepada anggota kelompok asal.

Hubungan antara kelompok asal dan kelompok ahli digambarkan sebagai berikut:

Kelompok Asal

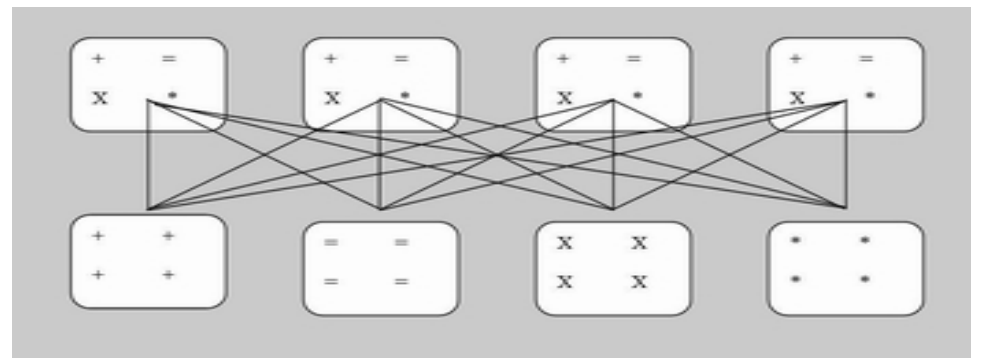

Kelompok Ahli

Gambar : Ilustrasi Kelompok Jigsaw

Pelaksanaan pembelajaran model jigsaw terdapat tiga tahapan sesuai dengan sintak dan dilaksanakan sebanyak dua kali pertemuan, dimana tahap satu dan dua dilaksanakan pada pertemuan yang sama (satu kali pertemuan). Berkaitan dengan tiga tahapan tersebut, masing-masing tahapan mempunyai prosedur yang 
berurutan yaitu pada tahap pertama merupakan tahap persiapan dimana pada urutan pertama, guru memberikan penjelasan terlebih dahulu tentang materi yang akan diajarkan, kemudian guru membuat program pengajaran untuk satu pokok bahasan yang dirancang dalam bentuk penggalan-penggalan sub pokok bahasan untuk kemudian setiap penggalan untuk satu kelompok yang didalamnya mencakup judul, penggalan tujuan pembelajaran, khususnya petunjuk pelaksanaan tugas-tugas yang harus diselesaikan. Pada urutan kedua, guru membagi suatu kelas menjadi beberapa kelompok, dengan setiap kelompok terdiri dari 4-6 siswa dengan kemampuan yang berbeda. Kelompok ini disebut kelompok asal. Jumlah anggota dalam kelompok asal menyesuaikan dengan jumlah bagian materi pelajaran yang akan dipelajari siswa sesuai dengan tujuan pembelajaran yang akan dicapai. Pada urutan ketiga, setelah kelompok asal ditentukan, guru kemudian membagi lagi siswa menjadi kelompok ahli dengan cara pengelompokanya berdasarkan urutan nomer bilangan yang sama berkumpul menjadi satu untuk membentuk kelompok ahli. Dan pada urutan keempat, guru meminta siswa untuk duduk bersama-sama sesuai dengan kelompok barunya yaitu kelompok ahli. Dalam model Jigsaw ini, setiap siswa diberi tugas mempelajari salah satu bagian materi pembelajaran tersebut.

Tahap kedua merupakan tahap pelaksanaan yang mengkondisikan siswa belajar bersama-sama di dalam tim ahli. Tahap kedua juga memiliki beberapa urutan yaitu pertama, setiap kelompok akan mempelajari materi yang berbeda yang telah diberikan oleh guru. Dengan adanya kondisi pengelompokan maka akan membuat siswa memiliki unsur kebersamaan yang dapat mendorong motivasi siswa untuk belajar bersamasama mendiskusikan materi yang menjadi bagiannya dalam kelompok. Semua siswa dengan materi pembelajaran yang sama belajar bersama dalam kelompok yang disebut kelompok ahli (Counterpart Group/ CG). Dalam kelompok ahli, siswa mendiskusikan bagian materi pembelajaran yang sama, serta menyusun rencana bagaimana menyampaikan kepada temannya jika kembali ke kelompok asal. Urutan ketiga pada tahap pelaksanaan yaitu guru mengawasi jalannya proses belajar, guru berpindah-pindah dari satu kelompok ke kelompok yang lain untuk memberikan bantuan jika ada masalah yang tidak dapat diselesaikan pada salah satu kelompok.

Tahap ketiga adalah tahap evaluasi, dimana urutan pertama yaitu setiap anggota kelompok ahli akan kembali ke kelompok asal untuk memberikan informasi yang telah diperoleh atau dipelajari dalam kelompok ahli. Urutan kedua yaitu setiap siswa mulai melaksanakan perannya untuk menyampaikan informasi yang telah mereka pelajari pada saat berada di kelompok ahli dengan cara membimbing atau menanyai sesama anggota kelompoknya secara bergantian terhadap hal-hal yang belum dimengerti, demikian pula halnya dalam menyelesaikan tugas, dan jika ada masalah yang tidak bisa diselesaikan barulah meminta bantuan guru.

Urutan ketiga adalah sebelum kegiatan pembelajaran berakhir, guru memberikan soal-soal latihan kepada setiap siswa yang berada pada tiap-tiap kelompok untuk mengetahui apakah tim ahli sudah menjalankan tugasnya dengan baik, dan jika mereka sudah memahami materi atau belum. Urutan keempat adalah guru mengingatkan siswa untuk mempelajari pokok bahasan/sub pokok bahasan di rumah untuk kemudian pada pertemuan selanjutnya hanya tinggal tes evaluasi. 
Secara keseluruhan keberhasilan pelaksanaan pembelajaran bahasa Inggris “ Reported Speech” dengan menggunakan model jigsaw dapat diterapkan dengan baik dan dapat mengoptimalkan serta memotivasi siwa untuk mencapai kemajuan hasil belajar. Hal itu ditunjukan dengan kegiatan guru dan siswa pada setiap tahapan yang dapat berjalan dengan baik dimana siswa yang tergabung dalam kelompok dengan kemampuan, asal, dan latar belakang keluarga yang beragam dalam satu kelas dapat saling mengajarkan atau menularkan informasi dan pengetahuan sehingga dapat mengatasi ketertinggalan dan menghasilkan kemajuan hasil belajar sebagaimana yang dilihat pada deskripsi berikut ini.

Deskripsi Data Hasil Belajar Kelas Jigsaw yang dikenai Perlakuan Kegiatan Belajar dengan Menggunakan Model Jigsaw.

Data hasil belajar yang diperoleh untuk kelas Jigsaw, yang terdiri dari 31 siswa diperoleh data-data statistik deskriptif sebagai berikut:

Tabel 1 : Data Hasil Belajar Kelas Jigsaw

Statistics

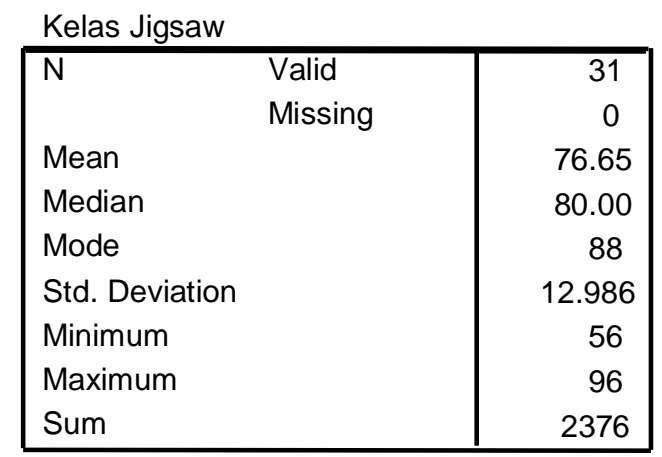

Data hasil belajar siswa kelas X-B SMA Taman Madya Probolinggo yang diajar menggunakan pembelajaran kooperatif model Jigsaw, memiliki rentang 56 sampai 96, dengan nilai rata-rata (mean) sebesar 76,65 dan nilai tengah (median) sebesar 80,0, sedangkan simpangan baku (standart deviation) sebesar 12,986. Jika disajikan dalam tabel distribusi frekuensi sebagai berikut:

Tabel 2 : Distribusi Frekuensi Hasil Belajar Kelas

\begin{tabular}{|c|c|c|c|c|c|}
\hline & & & s Jigsaw & & \\
\hline & & Frequency & Percent & Valid Percent & $\begin{array}{c}\text { Cumulative } \\
\text { Percent }\end{array}$ \\
\hline & $\begin{array}{ll}\text { Valid } & 56\end{array}$ & 3 & 9.7 & 9.7 & 9.7 \\
\hline & 60 & 3 & 9.7 & 9.7 & 19.4 \\
\hline & 64 & 2 & 6.5 & 6.5 & 25.8 \\
\hline & 68 & 2 & 6.5 & 6.5 & 32.3 \\
\hline & 72 & 4 & 12.9 & 12.9 & 45.2 \\
\hline & 76 & 1 & 3.2 & 3.2 & 48.4 \\
\hline & 80 & 4 & 12.9 & 12.9 & 61.3 \\
\hline & 84 & 2 & 6.5 & 6.5 & 67.7 \\
\hline & 88 & 5 & 16.1 & 16.1 & 83.9 \\
\hline & 92 & 2 & 6.5 & 6.5 & 90.3 \\
\hline & 96 & 3 & 9.7 & 9.7 & 100.0 \\
\hline & Total & 31 & 100.0 & 100.0 & \\
\hline
\end{tabular}


Berdasarkan tabel 1 dan 2, hasil penelitian membuktikan, bahwa nilai ratarata (mean) dan nilai tengah (median), serta frekuensi kemajuan prestasi siswa yang dicapai dari hasil belajar yang mendapatkan perlakuan pembelajaran cooperative learning model jigsaw menunjukkan peningkatan diatas nilai KKM (75). Dari hasil penelitian ini terungkap bahwa penerapan pembelajaran model jigsaw dapat mempengaruhi motivasi siswa, hal ini dapat dibuktikan dengan adanya hasil belajar yang meningkat baik (diatas KKM).

Beberapa kemungkinan penyebab dari pembelajaran model jigsaw dapat memberikan hasil yang baik dapat dikemukakan sebagai berikut: Pertama, model pembelajaran jigsaw merupakan model yang didesain untuk meningkatkan rasa tanggung jawab siswa terhadap pembelajarannya sendiri dan juga pembelajaran orang lain, dalam hal ini dengan penggunaan model jigsaw adalah bagaimana mengoptimalkan kemampuan siswa dalam kelompok dimana siswa tidak hanya mempelajari materi yang diberikan, tetapi mereka juga harus siap memberikan dan mengajarkan materi tersebut pada anggota kelompoknya yang lain. Dengan demikian, siswa saling tergantung satu dengan yang lain dan harus bekerja sama secara kooperatif untk mempelajari materi yang ditugaskan, seperti yang disampaikan oleh Sutrisno dan beberapa ahli pendidikan (2012) bahwa pembelajaran kooperatif banyak membantu siswa dalam memecahkan masalah sehingga siswa bukan hanya unggul dalam memahami konsep tetapi siswa juga dapat menumbuhkembangkan kemampuan serta memupuk sifat hubungan kerjasama antara kelompok, berani mengemukakan pendapat, memiliki rasa tanggung jawab, saling menghargai, bersikap sosial, berpikir kritis sesama anggota dan juga meningkatkan harga diri. Kedua, bahasa Inggris dianggap oleh siswa pelajaran yang sulit, adalah lebih mudah apabila dipelajari secara bersama, sehingga dalam hal tertentu siswa lebih paham dengan penjelasan temannya dari pada penjelasan gurunya, sebagaimana yang dikemukakan oleh Budiawan, dkk ( 2013) bahwa model jigsaw dapat mengembangkan seluruh potensi, kemampuan intelektual, emosional dan ketrampilan sehingga siswa dapat berpikir secara aktif, kreatif, efektif dan efisien yang akan mengurangi monopoli guru dalam penguasaan proses pembelajaran, dan dapat mengurangi kebosanan siswa dalam menerima pelajaran. Ketiga, pembelajaran jigsaw merupakan pembelajaran yang terpusat pada kegiatan siswa di dalam kelompok, sehingga dalam hal ini siswa belajar dari siswa lain yang memiliki kemampuan, asal, dan latar belakang keluarga yang beragam yang tidak jauh berbeda dari dirinya sendiri, sehingga secara tidak langsung akan tercipta rasa kebersamaan yang membuat mereka termotivasi dalam mengatasi ketertinggalan, yang pada akhirnya hasil belajar siswa dimungkinkan akan lebih baik. Hal ini juga ditegaskan oleh Budiawan, dkk ( 2013) dengan belajar bersama dapat memotivasi dan melibatkan siswa dalam proses belajar mengajar untuk meningkatkan hasil pembelajaran, yang artinya dengan belajar bersama siswa dapat berinovasi yang dapat membangkitkan motivasi tinggi yang diperkirakan akan memberikan pengaruh terhadap peningkatkan hasil belajar. Keempat, dengan belajar secara berkelompok akan memotivasi siswa untuk lebih mudah bertanya, lebih terbuka dengan teman sendiri di dalam kelompok 
dibandingkan dengan gurunya, karena dengan berkelompok, kondisi tersebut sangat membantu siswa untuk saling mengajarkan materi kepada temantemannya. Disiplin diri yang diberikan siswa dengan didasari oleh motivasi yang positif dari internal dan eksternal siswa yang memiliki perbedaan kemampuan, asal, dan latar belakang keluarga yang beragam akan melebur menjadi satu kebersamaan dalam kelompok demi terciptanya suatu kondisi yang tepat bagi siswa untuk secara maksimal menerima dan menularkan bahan ajaran, sehingga bahan ajaran/ tugas yang diberikan seorang guru tidak dianggap sebagai suatu beban oleh siswa melainkan sebagai suatu kebutuhan yang harus dipenuhi.

\section{SIMPULAN}

Berdasarkan hasil analisis dan dukungan asumsi teori sebagaimana dikemukakan diatas dapat ditegaskan bahwa pembelajaran cooperative learning model jigsaw terbukti memberikan pengaruh signifikan terhadap motivasi siswa yaitu berupa hasil belajar yang lebih baik (diatas KKM).

Oleh karena itu perlu kiranya tercipta pembelajaran yang kondusif agar dapat meningkatkan hasil belajar siswa secara maksimal. Salah satu cara agar dapat terwujud pembelajaran yang kondusif maka guru harus dapat memilih model pembelajaran yang tepat, karena model pembelajaran yang tepat akan dapat memberikan motivasi bagi siswa sehingga siswa dapat meningkatkan kemampuannya dalam proses pembelajaran.

Penerapan model jigsaw dapat memberikan motivasi dan mendorong siswa menjadi aktif dalam proses pembelajaran sehingga siswa tidak hanya diam, mencatat, dan mendengarkan ceramah dari guru, melainkan siswa akan terlibat secara aktif dalam proses pembelajaran bersama dalam kelompok dengan anggota lain dalam kelompoknya.

Jigsaw merupakan salah satu strategi pembelajaran untuk membantu memenuhi kebutuhan siswa. Rasa saling menghargai dan mengerti dibina diantara siswa melalui kerja sama. Setiap siswa dalam kelompok akan merasa bangga atas perannya dan juga belajar dari pengalamannya. Hal ini membantu memperkuat apa yang telah dipelajari dan diperoleh atas tanggung jawab yang dibebankan kepadanya. Ketika mereka belajar dalam kelompok, siswa juga mengembangkan kemampuan yang lebih baik untuk mendengarkan, berkonsentrasi, dan memahami apa yang dipelajari dengan cara yang bermakna. Penjelasan sesama teman lebih memungkinkan berhasil dibanding guru, dikarenakan, siswa melihat masalah dengan cara yang berbeda dibandingkan orang dewasa (guru) dan mereka menggunakan bahasa yang lebih akrab dan mudah dimengerti.

Pembelajaran jigsaw yang dalam pelaksanaannya mampu membuat suasana pembelajaran yang menarik dan menyenangkan ketika siswa mempelajari materi. Karena melalui model ini siswa bisa berdialog dan berinteraksi dengan sesama siswa secara terbuka dan interaktif dibawah bimbingan guru sehingga siswa terpacu dan termotivasi untuk menguasai bahan ajar yang disajikan. Peran guru dalam hal ini sebagai fasilitator dan pembimbing, artinya, guru hanya melakukan intervensi ketika betul-betul diperlukan oleh siswa. Kelebihan model jigsaw dalam penerapannya, bahwa siswa diajar untuk mandiri, dewasa dan punya rasa tanggung jawab dan setia kawan yang tinggi. 


\section{DAFTAR PUSTAKA}

Aritonang Keke.T. (2008). Minat dan Motivasi dalam Meningkatkan Hasil Belajar Siswa. Jurnal Pendidikan Penabur No.10/ Tahun ke-7/Juni 2008. Diambil dari http://www bpkpenabur.or.id /files. Diakses 5 Pebruari 2015

Budiawan, Ni Luh Kadek Alit Arsani. (2013). Jurnal Pendidikan Indonesia ISSN: 2303-288X. (Vol. 2. No. 1, April 2013) . Diakses 10 Pebruari 2015

Depdiknas. 2006. Bunga Rampai Keberhasilan Guru dalam Pembelajaran (SMA, SMK, dan SLB). Jakarta: Depdiknas.

Dimyati dan Mudjiono.( 2009). Belajar dan Pembelajaran. Jakarta: PT Rineka Cipta.

Hamalik, Oemar.(2006). Proses Belajar Mengajar. Jakarta: PT Bumi Aksara

Hamalik, O. (2008). Kurikulum dan Pembelajaran. Jakarta: Sinar Grafika. Hamalik,O. (2008). Proses Belajar Mengajar. Jakarta: Sinar Grafika.

Haryanto , (2012). Model Pembelajaran Kooperatif Jigsaw. Artikel Pendidikan. Diambil dari http://belajar psikologi. com/model-pembelajaran-kooperatifjigsaw/. diakses 5 Pebruari 2015

Lie. 2007. Cooperative Learning. Jakarta : Grasindo

Mengduo, Q. \& Xiaoling, J. (2010). Jigsaw Strategy as a Cooperative Learning Technique: Focusing on the Language Learners. C hinese Journal of Applied Linguistics (Bimonthly), 33(4).

Rusman, (2011). Model-Model Pembelajaran Mengembangkan Profesionalisme Guru. Jakarta: Raja Grafindo Persada
Sanjaya W. (2008). Strategi Pembelajaran, Jakarata: Kencana Prenada

Sriyanti, Lilik. 2009. Psikologi Pendidikan. Salatiga: STAIN Salatiga Press

Sudjana, Nana.(2010). Penilaian Hasil Proses Belajar Mengajar. (Cet. XV). Bandung: PT. RamajaRosdakarya.

Suyitno, I.(2011). Memahami Tindakan Pembelajaran; Cara Mudah dalam Perencanaan PTK. Bandung: PT. Refika Aditama.

Sutrisno.(2012). Journal of Innovative Science Education (1). http://journal. Unnes.ac.id/sji/index.php/jise. Diakses 10 Pebruari 2015

Tsay, Mina and Brady, Miranda. (2010). "A case study of cooperative learning and communication pedagogy" in Journal of the scholarship of Teaching and Learning. Vol 10, No 2. Available at http:/ www. Iupul.edu/josotl diakses 4 Pebruari 2015

Uno, Hamzah B., Abdul Karim Rauf, dan Najamuddin Petta Solong.(2008). Pengantar Teori Belajar dan Pembelajaran. (Cet. II). Gorontalo: Nurul Jannah.

Wahidmurni, Alifin Mustikawan, dan Ali Ridho.(2010). Evaluasi Pembelajaran: Kompetensi dan Praktik. Yogyakarta: Nuha Letera.

Wahidmurni, Alifin Mustikawan, dan Ali Ridho. (2010). Evaluasi Pembelajaran: Kompetensi dan Praktik. Yogyakarta: Nuha Letera. 